\title{
EFFECTS OF ANIMAL-ASSISTED THERAPY ON PARENT-REPORTED BEHAVIOUR AND MOTOR ACTIVITY OF CHILDREN WITH AUTISM SPECTRUM DISORDER
}

\section{WPŁYW ANIMALOTERAPII NA ZACHOWANIA I AKTYWNOŚĆ RUCHOWĄ DZIECI Z AUTYZMEM W OCENIE RODZICÓW}

\author{
Anna Kręgiel ${ }^{1(C, D, E, F)}, K^{2}$ amil Zaworski ${ }^{1(A, B, C, D, E, F)}$, Ewa Kołodziej $^{2(A, B, E)}$ \\ ${ }^{1}$ Pope John Paul II State School of Higher Education in Biała Podlaska, Poland \\ ${ }^{2}$ Neurology Ward with the Sub-Ward for Stroke and the Sub-Ward for Rehabilitation, the Independent Public Health \\ Care Institution in Lubartów, Poland
}

Authors' contribution Wkład autorów:

A. Study design/planning zaplanowanie badań B. Data collection/entry zebranie danych C. Data analysis/statistics dane - analiza i statystyki D. Data interpretation interpretacja danych E. Preparation of manuscript przygotowanie artykułu F. Literature analysis/search wyszukiwanie i analiza literatury G. Funds collection zebranie funduszy

\section{Summary}

Background. Autism spectrum disorder (ASD) is a neurobiological disorder characterised by abnormal development noted before three years of age. One of the forms of therapy suggested to children with ASD is animal-assisted therapy (AAT). AAT is a planned and organised therapeutic intervention that aims to improve physical, cognitive, behavioural, and socioemotional performance. The present study examined the effects of AAT on parent reports of their child's behaviour and motor activity.

Material and methods. The study group consisted of 50 parents ( 38 females and 12 males) of children diagnosed with ASD and who participated in AAT. All participants resided in the Lubelskie Voivodeship, Poland. A questionnaire was developed for parents for this study that included demographic information, and ten questions regarding the effects of AAT on their child with ASD.

Results. The most commonly reported forms of AAT among parents of children with ASD included canine-assisted therapy and equine-assisted therapy. Parents reported that AAT was associated with more animated gestures $(p=0.01)$, an increased frequency of verbal reactions $(p=0.02)$, and an increased frequency of expression of emotions and feelings $(p=0.05)$ among their children.

Conclusions. According to parents of children with ASD, AAT has positive effects on their child's emotion-related functioning, motor endurance, balance, and motor skills. However, access to AAT in the Lubelskie Voivodeship is limited.

Keywords: animal assisted therapy, autism, children, knowledge

\section{Streszczenie}

Wprowadzenie. Autyzm należy do zaburzeń neurobiologicznych, które charakteryzują się nieprawidłowym rozwojem, objawiajacych sie przed 3 rokiem życia. Jedną z form terapii proponowanych dzieciom z ASD jest animaloterapia. Terapia z udziałem zwierząt jest planowaną i zorganizowaną interwencją terapeutyczną, której podstawowym zadaniem jest poprawa fizycznego, poznawczego, behawioralnego oraz społeczno-emocjonalnego funkcjonowania. Celem pracy była ocena efektów działania animaloterapii w opinii rodziców dzieci z autyzmem.

Materiał i metody. Grupę badaną stanowiło 50 osób - 38 kobiet i 12 mężczyzn zamieszkujących województwolubelskie, u których dzieci zdiagnozowano ASD. Na potrzeby pracy skonstruowano autorski kwestionariusz ankiety składający się z metryczki oraz dziesięciu pytań dotyczących opinii rodziców dzieci z autyzmem na temat efektów działania animaloterapii.

Wyniki. Najczęściej wybieranymi formami animaloterapii były dogoterapia oraz hipoterapia. Rodzice, których dzieci uczestniczyły w zajęciach z udziałem zwierząt wskazywali wśród efektów terapii ożywioną gestykulację $(\mathrm{p}=0,01)$, zwiększone występowanie reakcji głosowych $(p=0,02)$ oraz częstsze okazywanie uczuć i emocji $(p=0,05)$.

Tables: 1

Figures: 1

References: 30

Submitted: 2019 Oct 3

Accepted: 2019 Nov 22
Wnioski. Terapia z udziałem zwierząt w opinii rodziców dzieci z autyzmem ma pozytywny wpływ na sferę emocjonalną, kondycję ruchową, równowagę oraz motorykę pacjentów. Dostęp do terapii z udziałem zwierząt na terenie województwa lubelskiego jest jednak ograniczony.

Słowa kluczowe: animaloterapia, autyzm, dzieci, wiedza

Kręgiel A, Zaworski K, Kołodziej E. Effects of animal-assisted therapy on parent-reported behaviour and motor activity of children with autism spectrum disorder. Health Prob Civil. 2019; 13(4): 273-278. https://doi.org/10.5114/hpc.2019.90013

Address for correspondence / Adres korespondencyjny: Kamil Zaworski, Pope John Paul II State School of Higher Education, Sidorska 95/97, 21-500 Biała Podlaska, e-mail: kamil_zaworski@wp.pl, phone +48506 764250

ORCID: Anna Kręgiel https://orcid.org/0000-0001-5454-6381, Kamil Zaworski https://orcid.org/0000-0001-5604-1862,

ORCID: Anna Kręgiel https://orcid.org/0000-0001-5454-63

Copyright: (c) Pope John Paul II State School of Higher Education in Biała Podlaska, Anna Kręgiel, Kamil Zaworski, Ewa Kołodziej. This is an Open Access journal, all articles are distributed under the terms of the Creative Commons Attribution-NonCommercial-ShareAlike 4.0 International (CC BY-NC-SA 4.0) License (http:// creativecommons.org/licenses/by-nc-sa/4.0/), allowing third parties to copy and redistribute the material in any medium or format and to remix, transform, and build upon the material, provided the original work is properly cited and states its license. 


\section{Introduction}

Autism spectrum disorder (ASD) is neurobiological disorder characterised by abnormal development noted before three years of age. Typical symptoms of ASD include pathological social functioning (e.g., social interactions, communication, and interests), as well as, limited and stereotypical motor activities. ASD is overall and presents under various conditions that are independent of the surroundings. At present, diagnostic reports and the scientific literature use the term 'ASD', which covers various pathologies, including autism, Asperger's syndrome, pervasive developmental disorder not otherwise specified, and childhood disintegrative disorders [1-6].

To date, the causes of ASD are yet to be identified; however, the causes are thought to be multifactorial in nature. Likely causes for ASD include genetic and hereditary factors, environmental and neurotoxic factors, allergies, food intolerances, immune system function impairment, and gestational and perinatal factors $[2,5,6,7]$.

Epidemiological studies are inconsistent regarding the frequency and incidence of ASD. Indeed, the reported rates of ASD differ based on the utilised diagnostic criteria. For example, a meta-analysis of 2012 epidemiological reports from across the globe showed that the incidence of ASD is approximately 62/10000 (or 1/160) [2]. The frequency of ASD is also thought to be increasing over time, which underscores that this is an ever-growing economic and medical problem. Taken together, the increasing frequency of ASD highlights the need for new evidence-based forms of therapy $[1,2,8,9,10]$.

Therapy of a child with an ASD should be a comprehensive process that is carefully planned and considers the complexity of the disorder, the needs of the patient, and his/her surroundings. The apparent need for treatment and therapy for ASD prompts the development of new approaches, and/or the refinement of already existing methods. One of the forms of therapy suggested for children with ASD is animal-assisted therapy (AAT). The positive effects of AAT are increasingly noted by specialists in medical rehabilitation $[2,3,11-15]$.

AAT is an organised and planned therapeutic intervention led by a specialist with appropriate theoretical and practical preparation in the field. AAT activities focus primarily on the improvement of cognitive, physical, socioemotional, and behavioural performance of the patient. A related form of animal-assisted classes is animalassisted education, wherein a qualified specialist performs interventions within the scope of education and pedagogics. Animal-assisted classes are strictly planned and organised, and they focus primarily on educational and didactic methods. The third prominent form of animal-assisted intervention is animal-assisted activity, which consists primarily of recreational classes and classes that encourage activity of patients and fosters the provision of mental comfort to people undergoing crisis situations $[3,11,16,17]$.

The animals most commonly used in rehabilitation activities are horses (i.e., equine-assisted therapy), dogs (canine-assisted therapy), cats (feline-assisted therapy) and dolphins (dolphin-assisted therapy) [13, 19-21]. The present study aimed to evaluate the effects of AAT on children with ASD, as measured by parent reports.

\section{Material and methods}

The study group consisted of 50 parents (38females, 12 males, age: $\mathrm{M}$ age $=38.1$ years, $\mathrm{Me}=39, \mathrm{SD}=9.35$ years) of children ( 30 boys, 20 girls, $\mathrm{M}$ age $=9.3$ years, $\mathrm{Me}=7.2, \mathrm{SD}=4.5$ ) diagnosed with ASD. All participants resided in the Lubelskie Voivodeship, Poland. A questionnaire was developed for parents for this study that included demographic information, and ten questions regarding the effects of AAT on their child with ASD. Statistical analysis was conducted with SPSS 17.0 suite (Softonic, USA). For the purposes of this paper, the following tests were applied: Phi assay and V Cramer test. In all tests, the significance level of $p<0.05$ was assumed.

\section{Results}

All respondents $(n=50)$ reported that their children participated in AAT. Participation in AAT did not differ by gender and age of children.

Most frequently (68\%), the parents reported learning about AAT on the Internet; $21 \%$ of parents reported learning about AAT from television, and 11\% from healthcare professionals (e.g., physician, physical therapist, nurse). At the same time, over a half (64\%) of the respondents reported that access to animal-assisted classes in the Lubelskie Voivodeship is limited. 30 (60\%) respondents indicated that their child was eager to participate in AAT; 4 (8\%) reported that their child participated reluctantly, and 16 (32\%) respondents had no opinion. Parents of 22 (44\%) children participated in AAT for more than 12 months; 17 (34\%) participated between 6 and 12 months, and 11 (22\%) participated in AAT for less than 6 months. All children participated in therapy once a week.

The most frequently reported forms of AAT used among study participants were canine-assisted therapy (40\%) and equine-assisted therapy (38\%) (Figure 1). 


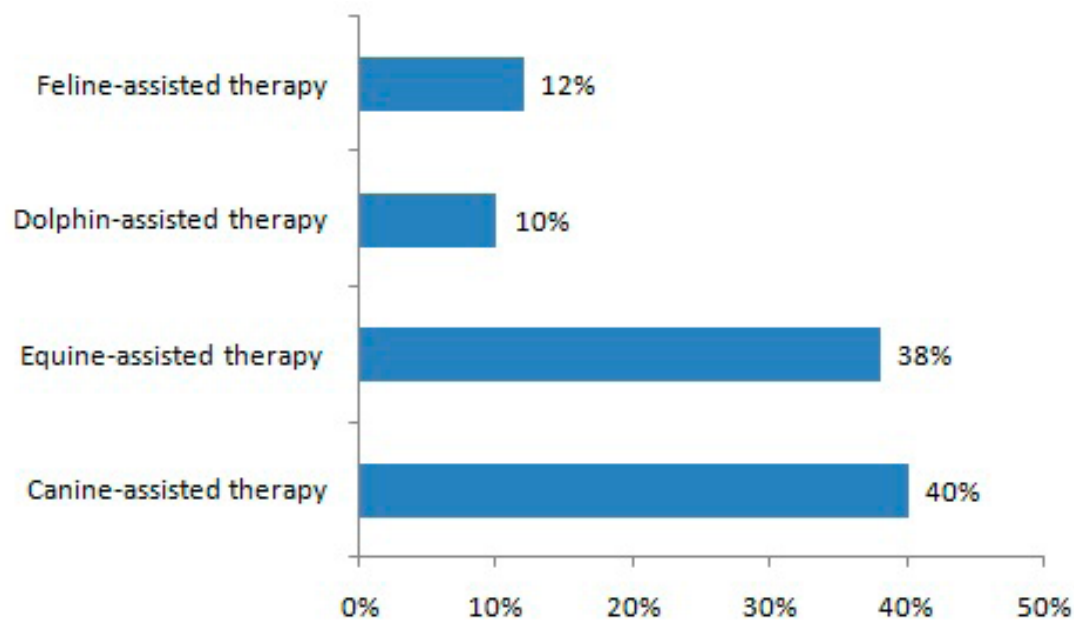

Figure 1. Forms of animal-assisted therapy (AAT) used by the children with autism $(n=50)$

Table 1 presents a parent-reported assessment of the effects of AAT on the emotional behaviours of autistic children. All of the positive changes indicated by the parents reached statistical significance $(p<0.05)$.

Table 1. Effects of contact with animals according to the respondents ( $\mathrm{n}=50$ parents)

\begin{tabular}{|c|c|c|c|c|}
\hline \multirow{2}{*}{\multicolumn{2}{|c|}{$\begin{array}{l}\text { What effects did you see in your child during his/her } \\
\text { contact with animals? }\end{array}$}} & \multicolumn{2}{|c|}{ Parent's assessment } & \multirow{2}{*}{$\mathbf{p}$} \\
\hline & & Yes & No & \\
\hline \multirow{2}{*}{ More frequent expression of feelings and emotions } & $\mathrm{N}$ & 44 & 6 & \multirow{2}{*}{$p=0.05$} \\
\hline & $\%$ & $88 \%$ & $12 \%$ & \\
\hline \multirow{2}{*}{ Lively gestures } & $\mathrm{N}$ & 49 & 1 & \multirow{2}{*}{$p=0.01$} \\
\hline & $\%$ & $98 \%$ & $2 \%$ & \\
\hline \multirow{2}{*}{ More frequent vocal and verbal reactions } & $\mathrm{N}$ & 43 & 7 & \multirow{2}{*}{$p=0.02$} \\
\hline & $\%$ & $86 \%$ & $14 \%$ & \\
\hline \multirow{2}{*}{ Increased responsibility and independence } & $\mathrm{N}$ & 26 & 24 & \multirow{2}{*}{$p=0.22$} \\
\hline & $\%$ & $52 \%$ & $48 \%$ & \\
\hline
\end{tabular}

27 (75\%) parents reported that participating in AAT improved their child's motor coordination; 24 (66.7\%) respondents reported an improvement in their child's concentration, 21 (58.3\%) reported an improvement in balance, and $20(55.6 \%)$ reported an improvement in motor skills.

Parents of children who participated in AAT reported that contact with animals had a positive impact on the child's activity ( $p=0.001, \mathrm{~V}$ Cramer $=0.58$ ). However, respondents reported that they are less aware of contraindications for animal-assisted interventions (e.g., allergies to certain animals or fear of animals) [22]. In addition, there was a significant negative correlation between disability level and awareness of contraindications such that parents of children with moderate degree of disability were less aware of contraindications for contact with animals $(p=0.002, \mathrm{~V}$ Cramer $=0.50$, Chi-square $=12.66(d f=2)$ ). Participation in animal-assisted classes was not associated with possession of a pet.

We found that the degree of disability is not related to participation in AAT $(p=0.06)$. Indeed, children with a higher degree of disability are also more likely to have various concomitant diseases; however, the difference was statistically significant only in the case of speech impediments $(p=0.05, \mathrm{~V}$ Cramer $=0.35$, Chi-square $=6.06$ $(d f=2))$.

\section{Discussion}

AAT may have positive effects on ASD patient outcomes in several domains. Most frequently, AAT has been shown to have multifaceted effects on the human body in terms of physical, mental, educational, and motivational functioning. At present, the health merits of an interaction between humans and animals have become a point of interest of many scientific disciplines, including medical, social, and psychological. 
In the present study, parents reported that children showed feelings and emotions more often, had animated gestures and vocal reactions, as well as, improved motor coordination, concentration, and balance following AAT. Grigore et al. found a positive effect of AAT in children in the form of improved verbal communication skills, improved eye contact, reduced motor hyperactivity, and increased expression of feelings [9].

Lanning et al. examined the effects of equine-assisted therapy on behaviour and quality of life of children with ASD [23]. In that study, the authors reported that a nine-week therapeutic regime was associated with positive changes in the study group in terms of physical activity, and in emotional and social functioning [23]. These improvements were not observed in the control group [23]. A similar study by Bass et al. assessed the impact of equine-assisted therapy on social, mental, and physical functioning of children with ASD [24]. In that study, the authors reported that, compared to the control group, the study group showed an increase in social relations, a decrease in distraction, and an increase in physical activity following equine-assisted therapy [24].

The present study showed a statistically significant higher frequency of speech impediments in children with a considerable degree of disability. Importantly, 71.1\% of parents reported an improvement in vocal and verbal reactions following their child's participation in AAT.

The reported improvement in vocal and verbal reactions is consistent with a study by Gabriels et al. [25], who reported an improvement in social behaviours, particularly an increase in communication and lower irritability, among young patients following a ten-week equine-assisted therapy regimen. In that study, the positive effects of therapy continued for at least six months [25]. Similarly, a study by Kern et al. reported that equine-assisted therapy was associated with a reduction in autistic symptoms, and an increase in quality of life among children [14]. These beneficial effects were evident for at least half a year following the end of therapy [14].

The literature review performed by Trzmiel et al. showed a positive effect of horseback riding on children with ASD, including a reduction in aggression, an improvement in motor functioning, and an improvement in social behaviours [26]. The present study did not find a statistically significant correlation between possessing a pet at home and participating in AAT. In contrast, Hall et al. showed that having a dog at home may have a positive effect on social problems among children with ASD [27].

Burgoyne et al. evaluated the impact of canine-assisted therapy on the behaviour and social relations of children with ASD [28]. In that study, the authors reported that patients using canine-assisted therapy were less exposed to environmental threats, and were more positively perceived by the society [28]. However, in a followup study performed by Fung and Leung in children with ASD, the authors reported that canine-assisted therapy was not superior to therapy sessions with an "artificial" dog [29]. Notwithstanding the results, the authors suggest that a dog may be a motivating factor for stimulating the development of speech in autistic children [29].

Families with a child with ASD have encountered barriers to therapy access, which could hinder the child's emotional, educational, and social growth. For example, Habik et al. examined therapeutic and rehabilitation activities and found that parents reported, for example, difficulty in accessing specialists, a high cost of therapy, and a lack of systematic physiotherapeutic procedures [30]. In line with these findings, we found that $64 \%$ of parents in the present study reported that access to AAT in the Lubelskie Voivodeship is limited.

According to the available forms of AAT, equine-assisted and canine-assisted therapy are the most commonly used and provide the best results [14, 23-28]. Indeed, the present study together with previous reports suggest that AAT can be used in the rehabilitation of children with ASD, and may be particularly useful for stimulating mental, social, and motivational functioning. It is important to note that the mechanism of AAT has not yet been fully explained. Therefore, it is imperative to perform further studies to examine the underlying mechanisms. Given that ASD is a growing medical problem, the search for new and more effective forms of treatment are needed to facilitate the growth of children with ASD.

\section{Conclusions}

1. Parents of children with ASD report that AAT has a positive effect on their child's emotional functioning.

2. Parents of children with ASD report that AAT has a positive effect on their child's motor fitness, balance, and motor activity.

3. Access to AAT in the Lubelskie Voivodeship is limited.

\section{Disclosures and acknowledgements}

The study was performed according to the International Code of Medical Ethics (Declaration of Helsinki). 


\section{References:}

1. Girczys-Połedniok K, Pudlo R, Agnieszka Szymlak A, Pasierb N. [The use of animal therapy in psychiatric practice]. Psychiatria. 2014; 11(3): 171-176 (in Polish).

2. Yates K, Couteur A. Diagnosing autism. Paediatrics and Child Health. 2009; 19(2): 55-59. https://doi.org/10.1016/j.paed.2008.10.010

3. Hoagwood KE, Acri M, Morrissey M, Peth-Pierce R. Animal-assisted therapies for youth with or at risk for mental health problems: a systematic review. Applied Developmental Science. 2017; 21(1): 1-13. https://doi.org/10.1080/10888691.2015.1134267

4. Armstrong C, Morrow L. [Medical neuropsychology]. Warszawa: Wydawnictwo Lekarskie PZWL; 2014 (in Polish).

5. Komender J, Wolańczyk T. [Emotional and behavioural disorders in children]. Warszawa: Wydawnictwo Lekarskie PZWL; 2014 (in Polish).

6. Kaciński M. [Neuropaediatrics]. Warszawa: Wydawnictwo Lekarskie PZWL; 2007 (in Polish).

7. Langauer-Lewowicka H, Rudkowski Z, Pawlas K. [Autism - environmental risk]. Medycyna Środowiskowa. 2016; 19(2): 19-23 (in Polish).

8. Grandin T, Panek R. [Autistic brain]. Kraków: Copernicus Center Press; 2016 (in Polish).

9. Grigore AN, Bazgan M. Effects of assisted animal therapy on the development of socio-emotional abilities of children with autism. Bulletin of the Transylvania University of Braşov. Series VII: Social Sciences. Law. 2017; 10(59): 231-238.

10. Frith U. [Autism and Asperger's syndrome]. Warszawa: Wydawnictwo Lekarskie PZWL; 2005 (in Polish).

11. The International Association of Human-Animal Interaction Organizations (IAHAIO). Iahaio White Paper 2014 [Internet]. Seattle: IAHAIO; 2014 [cited 2019 July 4]. Available from: http://iahaio.org/wp/wp-content/uploads/2017/05/iahaio-white-paper-final-nov-24-2014.pdf

12. Silva K, Lima M, Santos-Magalhaes A. Can dogs assist children with severe autism spectrum disorder in complying with challenging demands? An exploratory experiment with a live and a robotic dog. J Altern Complement Med. 2018; 24(3): 238-242. https://doi.org/10.1089/acm.2017.0254

13. Yap E, Scheinberg A, Williams K. Attitudes to and beliefs about disabilities. Complement Ther Clin Pract. 2017; 26: 47-52. https://doi.org/10.1016/j.ctcp.2016.11.009

14. Kern J, Fletcher C, Garver C, Mehta J, Grannemann BD, Knox KR, et al. Prospective trial of equine-assisted activities in autism spectrum disorder. Alternative Therapist in Health and Medicine. 2011 May-Jun; 17(3): 14-20.

15. Kuliński W. [Physical therapy in paediatrics]. Warszawa: Wydawnictwo Lekarskie PZWL; 2012 (in Polish).

16. Andreasen G, Stella T, Wilkison M, Szczech M, Hoelzel A, Hendricks L. Animal-assisted therapy and occupational therapy. Journal of Occupational Therapy, Schools \& Early Intervention. 2017; 10(1): 1-17. https://doi.org/10.1080/19411243.2017.1287519

17. Shen RZ, Xiong P, Chou UI, Hall BJ. "We need them as much as they need us": a systematic review of the qualitative evidence for possible mechanisms of effectiveness of animal-assisted intervention (AII). Complementary Therapies in Medicine. 2018; 41: 203-207. https://doi.org/10.1016/j.ctim.2018.10.001

18. Lasa SM, Bocanegra NM, Alcaide RV, Arratibel MA, Varela Donoso E, Ferriero G. [Animal assisted interventions in neurorehabilitation: a review of the most recent literature]. Neurología. 2015; 30(1): 1-7 (in Spanish). https://doi.org/10.1016/j.nrl.2013.01.012

19. Chmiel K, Kubińska Z, Derewiecki T. [Animal-assisted therapies in healing of different disabilities]. Problemy Higieny i Epidemiologii. 2014; 95(3): 591-595 (in Polish).

20. Ortiz-Sanchez P, Mulas F, Abad-Mas L, Roca P, Gandia-Beneto R. [Randomised controlled study of inter-hemispheric electroencephalographic coherence following assisted therapy with dolphins in children with autism spectrum disorders]. Rev Neurol. 2018; 66(Supl. 1): 65-70 (in Spanish). https://doi.org/10.33588/rn.66S01.2017537

21. Cerino S, Borgi M, Fiorentini I, Correale C, Lori A, Cirulli F. Equine-assisted intervention in a child diagnosed with autism spectrum disorder: a case report. Riv Psichiatr. 2016; 51(6): 270-274.

22. Goddard AT, Gilmer MJ. Role and impact of animals with pediatric patients. Pediatric Nursing. 2015; 41(2): 65-71.

23. Lanning B, Baier M, Ivey-Hatz J, Krenek N, Tubbs JD. Effects of equine assisted activities on autism spectrum disorder. Journal of Autism Developmental Disorders. 2014; 44(8): 1897-907.

https://doi.org/10.1007/s10803-014-2062-5 
24. Bass M, Duchowny C, Llabre M. The effect of therapeutic horseback riding on social functioning in children with autism. Journal of Autism Developmental Disorders. 2009; 39(9): 1261-7. https://doi.org/10.1007/s10803-009-0734-3

25. Gabriels R, Pan Z, Guérin N, Dechant B, Mesibov G. Long-term effect of therapeutic horseback riding in youth with autism spectrum disorder: a randomized trial. Frontiers and Veterinary Science. 2018; 5: $156-158$. https://doi.org/10.3389/fvets.2018.00156

26. Trzmiel T, Purandare B, Michalak M, Zasadzka E, Pawlaczyka M. Equine assisted activities and therapies in children with autism spectrum disorder: a systematic review and a meta-analysis. Complementary Therapies in Medicine. 2019; 42: 104-113. https://doi.org/10.1016/j.ctim.2018.11.004

27. Hall SS, Wright HF, Mills DS. What factors are associated with positive effects of dog ownership in families with children with autism spectrum disorder? The development of the Lincoln Autism Pet Dog Impact Scale. Plos One. 2016; 11(2): e0149736. https://doi.org/10.1371/journal.pone.0149736

28. Burgoyne L, Dowling L, Fitzgerald A, Connolly M, Browne JP, Perry IJ. Parents' perspectives on the value of assistance dogs for children with autism spectrum disorder: a cross-sectional study. BMJ Open. 2014; 4(6). https://doi.org/10.1136/bmjopen-2014-004786

29. Fung $S$, Leung A. Pilot study investigating the role of therapy dogs in facilitating social interaction among children with autism. Journal of Contemporary Psychotherapy. 2014; 44(4): 253-262. https://doi.org/10.1007/s10879-014-9274-z

30. Habik N, Chmielewski J, Florek-Łuszczki M, Zagórski J, Szpringer M. [Psychosocial problems in parents of children with autism spectrum disorders]. Rozprawy Społeczne. 2017; 11(4): 22-27 (in Polish).

https://doi.org/10.29316/rs.2017.34 